\title{
Hysterolaparoscopy as a one-time approach in infertility: a prospective study
}

\author{
Rini Sutaria*, Richa Singh, Sriram Gopal
}

Department of Obstetrics and Gynecology, D. Y. Patil Medical College, Navi Mumbai, Maharashtra, India

Received: 11 May 2020

Accepted: 16 June 2020

\section{*Correspondence:}

Dr. Rini Sutaria,

E-mail: rini.sutaria@gmail.com

Copyright: (C) the author(s), publisher and licensee Medip Academy. This is an open-access article distributed under the terms of the Creative Commons Attribution Non-Commercial License, which permits unrestricted non-commercial use, distribution, and reproduction in any medium, provided the original work is properly cited.

\begin{abstract}
Background: The prevalence of infertility ranges from $3.5 \%$ to $16.7 \%$ in more developed nations and from $6.9 \%$ to $9.3 \%$ in less developed nations, with an estimated overall median prevalence of $9 \%$. The present study was aimed to evaluate the role of hysterolaparoscopy in the study of primary and secondary infertility, to identify the various pathological conditions in female reproductive tract leading to primary/ secondary infertility, to develop a plan for therapy and management at the same time.

Methods: This is a one-year prospective study conducted in obstetrics and gynecology department at D. Y. Patil hospital, Navi Mumbai, Maharashtra, India. All infertility patients seen in outpatient department, who were medically fit, willing for surgery and willing to get enrolled for study were included in this study.

Results: Out of total 120 cases for infertility evaluated, tubal factor is the most common cause (28.3\%) in both primary $(23.3 \%)$ and secondary $(43.3 \%)$ infertility group as seen on laparoscopy. Followed by ovarian factors $(28.3 \%)$, peritoneal $(11.6 \%)$ and uterine factors $(10.8 \%)$. In 27 cases $(22 \%)$, there were no detectable pathology at laparoscopy. In this study, hysteroscopy findings show $5.8 \%$ cases to have submucous fibroid uterus, $3.3 \%$ submucous polyp, $1.6 \%$ subseptate uterus, $0.8 \%$ septate uterus, $0.8 \%$ intrauterine adhesions, $0.8 \%$ bicornuate uterus and cervical stenosis $1.6 \%$ of patients.

Conclusions: From this study, it is concluded that the diagnostic hysteroscopy and laparoscopy is an effective and safe tool in evaluation of female infertility. It provides direct and magnified view of all pelvic organs.
\end{abstract}

Keywords: Hysteroscopy, Hysterolaparoscopy, Infertility, Laparoscopy

\section{INTRODUCTION}

Infertility is one of the most important but least taken care of reproductive health problems in developing countries. It is frequently considered a tragedy and a curse for the couple, impacting on the entire family and the community. ${ }^{1}$ The prevalence of infertility ranges from $3.5 \%$ to $16.7 \%$ in more developed nations and from $6.9 \%$ to $9.3 \%$ in less developed nations, with an estimated overall median prevalence of $9 \% .^{2}$

Hysterolaparoscopy thus provides a comprehensive investigative procedure in which various factors causing female infertility can be assessed at one sitting. Operative laparoscopy helps not only with defining the status of the pelvic organs, but with the treatment of them, so it may give patients a chance for spontaneous conception.

In the case of irreversibly damaged oviducts the operative laparoscopy increases the success rate of the modern assisted reproductive techniques. ${ }^{3}$

During the hysterolaparoscopy, necessary consent was taken hysterolaparoscopy, necessary consents are taken beforehand, anticipating the pathologies and the necessary surgical interventions can be performed accordingly (cystectomy, ovarian resection, endometriosis, electrocoagulation). 
The aim of this study was to see the role of hysterolaparoscopy in assessing various factors like uterine, tubal, ovulatory and cervical and their prevalence in infertility.

\section{METHODS}

This prospective study of 120 patients was conducted in department of obstetrics and gynecology at D. Y. Patil Hospital, Navi Mumbai, from June 2017 to May 2018.

\section{Inclusion criteria}

- All infertility patients seen in outpatient department of obstetrics and gynecology

- All patients who are medically fit to be posted for surgery.

\section{Exclusion criteria}

- All medically unfit patient for surgery

- Patients not willing to get enrolled in the study.

Patient's medical history followed by her examination and relevant examination of the husband was carried out. The investigations consisted of hemoglobin percentage, total WBC count, urine examination, test for syphilis, $\mathrm{HIV}, \mathrm{HbsAg}$, blood grouping and Rh typing, transvaginal sonography, hormonal tests such as prolactin levels and thyroid profile was done.

Patient was admitted in the hospital a day before to the procedure and aesthetic check-up was done. The procedure was carried out in the follicular phase.

An informed consent was taken from all the patients.

Hysterolaparoscopy was performed under general anaesthesia. First, hysteroscopy was performed to visualize uterus, ostia, endocervical canal and then observations made on laparoscopy were recorded in the following way:

General: To start with a general assessment of peritoneal cavity especially the lower part of abdomen and pelvis was made to note any obvious pathology in the form of adhesions or any gross deviations from the normal appearances.

Uterus: The size and shape of the uterus was recorded. Any apparent congenital malformations like arcuate uterus, bicornuate uterus or rudimentary uterine horn was looked for and recorded. If any adhesions existed between the uterus, adnexa, omentum, etc. were recorded.

Tubes: Tubes were traced from cornual end to fimbrial end. Apparent tortuosity of the tubes, any pathology affecting or involving the tubes was looked for and recorded.
Ovaries: The size and shape of the ovaries was carefully noted. If one or both ovaries were found cystic, a visual assessment in respect of Stein-Leventhal syndrome was made.

Pelvic peritoneum including pouch of Douglas: Any pathology in the form of endometriosis, pelvic inflammation or residual adhesions was recorded when seen.

Uterovesical pouch: Observed for any evidence of endometriosis, adhesions and tubercles.

Tubal patency test: Done under vision by instilling methylene blue dye intracervical.

Hysteroscopy: Uterine cavity, endocervical canal was noted for septum, polyp, fibroid, tubal ostia or other pathology.

\section{RESULTS}

\section{Type of infertility}

Out of total 120 cases for infertility evaluated, primary infertility was $90(75 \%)$ and secondary infertility was 30 $(25 \%)$.

\section{Distribution of the patients by age}

From the Table 1, it has been seen that majority of patient in primary infertility belongs to the age of 26 to 30 years and in secondary infertility belongs to the age of 31 to 35 years. Totally $23.3 \%$ cases presented in the age group of 21 to 25 years, $40 \%$ cases from 26 to 30 years, $28.3 \%$ cases from 31 to 35 years, $8.3 \%$ cases from 36 to 40 years. In this study, statistically significant association was not found between patients age and type of infertility (Table 1).

Table 1: Distribution of the patients by age.

\begin{tabular}{|llll|}
\hline $\begin{array}{l}\text { Age in } \\
\text { years }\end{array}$ & $\begin{array}{l}\text { Primary } \\
\text { infertility }\end{array}$ & $\begin{array}{l}\text { Secondary } \\
\text { infertility }\end{array}$ & Total \\
\hline $21-25$ & $24(26.6 \%)$ & $4(13.3 \%)$ & $28(23.3 \%)$ \\
\hline $26-30$ & $39(43.3 \%)$ & $9(30 \%)$ & $48(40 \%)$ \\
\hline $31-35$ & $20(22.2 \%)$ & $14(46.6 \%)$ & $34(28.3 \%)$ \\
\hline $36-40$ & $7(7.7 \%)$ & $3(10 \%)$ & $10(8.3 \%)$ \\
\hline Total & $90(75 \%)$ & $30(25 \%)$ & $120(100 \%)$ \\
\hline
\end{tabular}

\section{Duration of infertility}

As seen in Table 2, in $68(56.6 \%)$ cases, the duration of infertility was from 1 to 5 years. Amongst 68 cases primary infertility were $57(63.3 \%)$ and secondary infertility were $11(36.6 \%)$. 
In $73(30.8 \%)$ cases, the duration of infertility was from 6 to 10 years. Amongst 15 cases, $12(13.3 \%)$ had primary infertility and $3(10 \%)$ had secondary infertility. In this study, statistically significant association was found between duration of infertility and type of infertility (Table 2).

Table 2: Duration of infertility.

\begin{tabular}{|llll|}
\hline $\begin{array}{l}\text { Duration of } \\
\text { infertility }\end{array}$ & $\begin{array}{l}\text { Primary } \\
\text { infertility }\end{array}$ & $\begin{array}{l}\text { Secondary } \\
\text { infertility }\end{array}$ & Total \\
\hline 1-5 years & $57(63.3 \%)$ & $11(36.6 \%)$ & $68(56.6 \%)$ \\
\hline 6-10 years & $21(23.3 \%)$ & $16(53.3 \%)$ & $37(30.8 \%)$ \\
\hline 10-15 years & $12(13.3 \%)$ & $3(10 \%)$ & $15(12.5 \%)$ \\
\hline Total & $90(75 \%)$ & $30(25 \%)$ & $120(100 \%)$ \\
\hline$\chi^{2}=9.59$, df $=2$, p value $=0.008$ & & \\
\hline
\end{tabular}

\section{USG findings}

In this study, out of 120 cases, $59.1 \%$ patients have to be found normal USG findings, $17.5 \%$ have PCOS, $9.1 \%$ ovarian cyst, $10 \%$ of them with fibroid uterus, and $4.1 \%$ adnexal mass. In this study, significant association was seen between USG findings and type of infertility (Table 3).

Table 3: USG findings.

\begin{tabular}{|llll|}
\hline $\begin{array}{l}\text { USG } \\
\text { findings }\end{array}$ & $\begin{array}{l}\text { Primary } \\
\text { infertility }\end{array}$ & $\begin{array}{l}\text { Secondary } \\
\text { infertility }\end{array}$ & Total \\
\hline Normal & $56(62.2 \%)$ & $15(50 \%)$ & $71(59.1 \%)$ \\
\hline PCOS & $17(18.8 \%)$ & $4(13.3 \%)$ & $21(17.5 \%)$ \\
\hline Ovarian cyst & $7(7.7 \%)$ & $4(13.3 \%)$ & $11(9.1 \%)$ \\
\hline Fibroid & $9(10 \%)$ & $3(10 \%)$ & $12(10 \%)$ \\
\hline Adnexal mass & $1(11.1 \%)$ & $4(13.3 \%)$ & $5(4.1 \%)$ \\
\hline Total & $90(75 \%)$ & $30(25 \%)$ & $120(100 \%)$ \\
\hline
\end{tabular}

$\chi^{2}=9.78, \mathrm{df}=4, \mathrm{p}$ value $=0.04$.

\section{Uterine factors in laparoscopy}

In this study, uterine factors accounted for $10.8 \%$ of causes of infertility, out of which $10 \%$ cases presented with fibroid uterus. Fibroid uterus more commonly found in primary infertility group. One case $(0.8 \%)$ of primary infertility with bicornuate uterus was also seen (Figure 1).

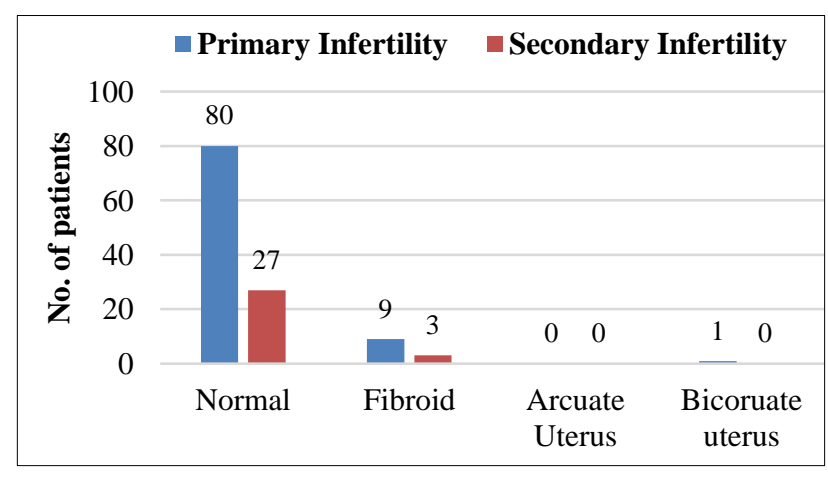

Figure 1: Uterine factors in laparoscopy.
Table 4: Tubal factors in laparoscopy with chromopertubation.

\begin{tabular}{|llll|}
\hline $\begin{array}{l}\text { Tubal } \\
\text { factors }\end{array}$ & $\begin{array}{l}\text { Primary } \\
\text { infertility }\end{array}$ & $\begin{array}{l}\text { Secondary } \\
\text { infertility }\end{array}$ & Total \\
\hline $\begin{array}{l}\text { B/L tubal } \\
\text { patent }\end{array}$ & $69(76.6 \%)$ & $17(56.6 \%)$ & $86(71.6 \%)$ \\
\hline $\begin{array}{l}\text { B/L tubal } \\
\text { block }\end{array}$ & $12(13.3 \%)$ & $6(20 \%)$ & $18(15 \%)$ \\
\hline $\begin{array}{l}\text { U/L tubal } \\
\text { block }\end{array}$ & $8(8.8 \%)$ & $4(13.3 \%)$ & $12(10 \%)$ \\
\hline Hydrosalpinx & $1(1.1 \%)$ & $3(10 \%)$ & $4(3.3 \%)$ \\
\hline Total & $90(75 \%)$ & $30(25 \%)$ & $120(100 \%)$ \\
\hline$\chi^{2}=7.7, \mathrm{df}=3, \mathrm{p}$ value $=0.05$ & & \\
\hline
\end{tabular}

\section{Tubal factors in laparoscopy with chromopertubation}

In the study, tubal factors accounted for $28.4 \%$ cases of infertility and $23.3 \%$ cases belongs to primary, $43.3 \%$ cases belong to secondary infertility group. Totally $15 \%$ cases presented with bilateral tubal block and $10 \%$ cases with unilateral tubal block, 3.3\% hydrosalpinx. In this study, no statistically significant association was found between tubal factors and type of infertility (Table 4).

Table 5: Ovarian factors in laparoscopy.

\begin{tabular}{|llll|}
\hline $\begin{array}{l}\text { Ovarian } \\
\text { factors }\end{array}$ & $\begin{array}{l}\text { Primary } \\
\text { infertility }\end{array}$ & $\begin{array}{l}\text { Secondary } \\
\text { infertility }\end{array}$ & Total \\
\hline Normal & $66(73.3 \%)$ & $20(66.6 \%)$ & $86(71.6 \%)$ \\
\hline PCOS & $17(18.8 \%)$ & $4(13.3 \%)$ & $21(17.5 \%)$ \\
\hline Ovarian cyst & $6(6.6 \%)$ & $5(16.6 \%)$ & $11(9.1 \%)$ \\
\hline $\begin{array}{l}\text { Tubo-ovarian } \\
\text { mass }\end{array}$ & $1(1.1 \%)$ & $1(3.3 \%)$ & $2(1.6 \%)$ \\
\hline Total & $90(75 \%)$ & $30(25 \%)$ & $120(100 \%)$ \\
\hline
\end{tabular}

\section{Ovarian factors in laparoscopy}

As shown in Table 5, ovarian factors responsible for $28.3 \%$ cases, of which majority of them have PCOS $(17.5 \%)$. In primary infertility $18.8 \%$ PCOS, $6.6 \%$ ovarian cyst, $1.1 \%$ Tubo-ovarian mass present. In secondary infertility group $13.3 \%$ PCOS, $16.6 \%$ ovarian cyst, 3.3\% Tubo-ovarian mass present. Out of total 11 ovarian cyst, 5 patients had chocolate cyst, 1 had dermoid cyst and remaining 5 had simple hemorrhagic cyst. In this study, no statistically significant association was found between ovarian factors and type of infertility (Table 5).

\section{Peritoneal factors in laparoscopy}

In this study, peritoneal factors responsible for $11.6 \%$ of total cases. In primary infertility $6.6 \%$ presented with endometriosis, $1.1 \%$ pelvic adhesion present. In secondary infertility, $13.3 \%$ pelvic adhesion and $10 \%$ endometriosis. In this study, statistically significant association was found between peritoneal factors and type of infertility (Table 6). 
Table 6: Peritoneal factors in laparoscopy.

\begin{tabular}{|c|c|c|c|}
\hline $\begin{array}{l}\text { Peritoneal } \\
\text { factor }\end{array}$ & $\begin{array}{l}\text { Primary } \\
\text { infertility }\end{array}$ & $\begin{array}{l}\text { Secondary } \\
\text { infertility }\end{array}$ & Total \\
\hline Normal & $83(92.2 \%)$ & $23(76.6 \%)$ & $106(88.3 \%)$ \\
\hline Endometriosis & $6(6.6 \%)$ & $3(10 \%)$ & $9(7.5 \%)$ \\
\hline Pelvic adhesion & $1(1.1 \%)$ & $4(13.3 \%)$ & $5(4.16 \%)$ \\
\hline Total & $90(75 \%)$ & $30(25 \%)$ & $120(100 \%)$ \\
\hline
\end{tabular}

\section{Various factors of infertility in laparoscopy}

In this study it has been found, that tubal factor is the most common cause $(28.3 \%)$ in both primary $(23.3 \%)$ and secondary $(43.3 \%)$ in fertility group. Followed by ovarian factors $(28.3 \%)$, peritoneal $(11.6 \%)$ and uterine factors $(10.8 \%)$. In 27 cases $(22 \%)$, there were no detectable pathology at laparoscopy. Total number of cases is not shown in the figure as many patients have more than one pathology at laparoscopy. In this study, no statistically significant association was found between tubal factors and type of infertility (Figure 2).

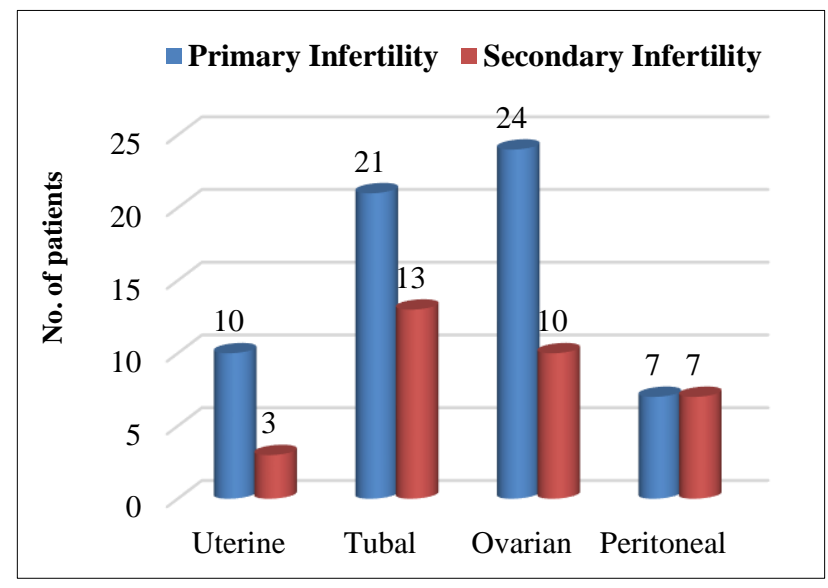

Figure 2: Factors of infertility in laparoscopy.

Table 7: Findings on hysteroscopy.

\begin{tabular}{|llll|}
\hline $\begin{array}{l}\text { Factors of } \\
\text { infertility }\end{array}$ & $\begin{array}{l}\text { Primary } \\
\text { infertility }\end{array}$ & $\begin{array}{l}\text { Secondary } \\
\text { infertility }\end{array}$ & Total \\
\hline $\begin{array}{l}\text { Submucous } \\
\text { fibroid }\end{array}$ & $4(4.4 \%)$ & $3(10 \%)$ & $7(5.8 \%)$ \\
\hline $\begin{array}{l}\text { Submucous } \\
\text { polyp }\end{array}$ & $3(3.3 \%)$ & $1(3.3 \%)$ & $4(3.3 \%)$ \\
\hline $\begin{array}{l}\text { Intrauterine } \\
\text { adhesion }\end{array}$ & 0 & $1(3.3 \%)$ & $1(0.8 \%)$ \\
\hline $\begin{array}{l}\text { Sub septate } \\
\text { uterus }\end{array}$ & $2(2.2 \%)$ & 0 & $2(1.6 \%)$ \\
\hline Septate uterus & $1(1.1 \%)$ & 0 & $1(0.8 \%)$ \\
\hline $\begin{array}{l}\text { Bicornuate } \\
\text { uterus }\end{array}$ & $1(1.1 \%)$ & 0 & $1(0.8 \%)$ \\
\hline $\begin{array}{l}\text { Cervical } \\
\text { stenosis }\end{array}$ & $2(2.2 \%)$ & 0 & $2(1.6 \%)$ \\
\hline Total & $90(75 \%)$ & $30(25 \%)$ & $120(100 \%)$ \\
\hline
\end{tabular}

\section{Findings on hysteroscopy}

In this study $5.8 \%$ cases found to have submucous fibroid uterus, 3.3 submucous polyp, $1.6 \%$ subseptate uterus, $0.8 \%$ Septate uterus, $0.8 \%$ intrauterine adhesions, $0.8 \%$ bicornuate uterus and cervical stenosis $1.6 \%$ of patients. (Table 7).

\section{DISCUSSION}

Infertility is defined as failure to achieve pregnancy within a year of regular unprotected intercourse. ${ }^{4}$ Pathology like submucous fibroid and endometrial polyps, result in abnormal uterine bleeding, infertility or both. Congenital anomalies of female genital tract are associated with higher rate of infertility..$^{5}$

Diagnostic hysteroscopy provides a reliable information in evaluation of uterine cavity and detection of intrauterine diseases. Mean prevalence of uterine malformation in general population is $4.3 \%$ in infertility is $3.5 \%$ and in recurrent pregnancy loss $13 \% .6$ The incidence of uterine anomaly is $7.6 \%$. Subseptate and septate uterus is the most common uterine malformation in this study, which is undiagnosed by prior USG. Septate uterus is the most common uterine anomaly associated with increased reproductive failure rates.

Complication rate of diagnostic hysteroscopy is as low as $0.012 \%$. In view of low complication, less timeconsuming hysteroscopy could be done in all infertility patients undergoing diagnostic laparoscopy.

Diagnostic laparoscopy is the standard method in diagnosis of tubal, peritoneal pathologies, endometriosis.

The result of this study is compared with others studies.

Table 8: Comparative studies of type of infertility.

\begin{tabular}{|llll|}
\hline & $\begin{array}{l}\text { Ramesh } \\
\text { B et } \text { al }^{7}\end{array}$ & $\begin{array}{l}\text { Mehta } \\
\text { A V et } \text { al }^{8}\end{array}$ & $\begin{array}{l}\text { Present } \\
\text { study }^{-}\end{array}$ \\
\hline Primary infertility & $66 \%$ & $69 \%$ & $75 \%$ \\
\hline Secondary infertility & $34 \%$ & $31 \%$ & $25 \%$ \\
\hline
\end{tabular}

In the present study out of 120 cases of infertility, primary infertility is $75 \%$ and secondary infertility is $25 \%$. Similar result was found in AV Mehta et al where as in Ramesh B et al, primary infertility was $66 \%$ and secondary infertility $34 \%$. $^{7,8}$

In this study majority of patients of primary infertility $(43.3 \%)$ in the age group of 26-30 years and secondary infertility $(46.6 \%)$ in the age of $31-35$ years. Ramesh et al, shows common age group in primary infertility was 21-25 years, in secondary infertility was 26-30 years. $^{7}$ Present study shows primary infertility group more commonly present with 1-5 years duration (63.3\%) and secondary infertility present with 6-10 years duration 
$(53.3 \%)$. Ramesh et al, found that both groups presented in 4-7 years duration (Table 8$)^{7}$

Table 9: Comparative studies of uterine factors in laparoscopy.

\begin{tabular}{|llll|}
\hline Uterine factors & $\begin{array}{l}\text { Sajida } \\
\text { et al }^{9}\end{array}$ & $\begin{array}{l}\text { Godinjak } \\
\text { et al }^{10}\end{array}$ & $\begin{array}{l}\text { Present } \\
\text { study }\end{array}$ \\
\hline Fibroid uterus & $4.8 \%$ & $8.6 \%$ & $10 \%$ \\
\hline Uterine anomaly & $6.48 \%$ & $36.5 \%$ & $0.8 \%$ \\
\hline
\end{tabular}

From the Table 9 it has been found that uterine pathology in $10.8 \%$ cases, among this fibroid uterus is $10 \%$. In fibroid uterus distortion of endometrial cavity and impaired gamete transport lead to adverse pregnancy outcome.

Godinjak $\mathrm{Z}$ et al, found fibroid in $8.6 \%$, uterine anomaly in $36.5 \%$ cases. $^{10}$ Sajida et al, found fibroid in $4.8 \%$, uterine anomaly in $6.45 \%$ cases (Table 9 ). ${ }^{9}$

In the present study authors have found tubal factors lead to maximum number of infertilities. Tubal block was present in $25 \%$ cases and hydrosalpinx in $3.3 \%$ cases. This may be due to increased incidence of pelvic inflammatory diseases, chronic infections and genital tuberculosis. Tubal damage increases with the number and severity of episodes of PID. Sajida et al, found tubal block in $35.5 \%$ whereas in Godinjak $\mathrm{Z}$ et al, found tubal block in $13.3 \% .^{9,10}$ Hydrosalpinx was not found in both these studies (Table 10).

Table 10: Comparative studies of tubal factors in laparoscopy.

\begin{tabular}{|llll|}
\hline Tubal factors & $\begin{array}{l}\text { Sajida } \\
\text { et } \text { al }^{\mathbf{9}}\end{array}$ & $\begin{array}{l}\text { Godinjak } \\
\text { et al }^{\mathbf{1 0}}\end{array}$ & $\begin{array}{l}\text { Present } \\
\text { study }\end{array}$ \\
\hline B/L patent & $64.5 \%$ & $88 \%$ & $71.6 \%$ \\
\hline B/L block & 16.25 & $5 \%$ & $15 \%$ \\
\hline U/L block & $19.3 \%$ & $8.33 \%$ & $10 \%$ \\
\hline Hydrosalpinx & - & - & $3.3 \%$ \\
\hline
\end{tabular}

Table 11: Comparative studies of ovarian factors in laparoscopy.

\begin{tabular}{|llll|}
\hline Ovarian factors & $\begin{array}{l}\text { Sajida } \\
\text { et } \mathbf{a l}^{\mathbf{9}}\end{array}$ & $\begin{array}{l}\text { Godinjak } \\
\text { et al }{ }^{\mathbf{1 0}}\end{array}$ & $\begin{array}{l}\text { Present } \\
\text { study }\end{array}$ \\
\hline PCOS & $19.35 \%$ & - & $17.5 \%$ \\
\hline Ovarian cyst & $4.8 \%$ & $4.44 \%$ & $9.1 \%$ \\
\hline TO mass & - & - & $1.6 \%$ \\
\hline
\end{tabular}

In the present study ovarian factors accounts for $28.2 \%$ cases. Among these PCOS is the most common cause in $17.5 \%$ cases followed by ovarian cyst in $9.1 \%$, TO mass in $1.6 \%$ cases.

In PCOS anovulation, failure of corpus luteum development, decreased progesterone and hyperandrogenism lead to infertility. Sajida et al, found
PCOS $19.35 \%$ and ovarian cyst in $4.8 \%$ cases. Godinjak $\mathrm{Z}$ et al, found only ovarian cyst in $4.44 \%$ cases (Table 11). 9,10

In the present study, it has been found that endometriosis in $7.5 \%$, pelvic adhesion in $4.1 \%$ cases. Pelvic adhesions can be due to infection or previous surgeries. It leads to peritubal and omental adhesions which produces distortion of pelvic anatomy. Sajida et al, found Endometriosis in $8 \%$, pelvic adhesion in $11.2 \%$ cases. $^{9}$ Godinjak Z et al, found endometriosis in $14.16 \%$, pelvic adhesion in $11.11 \%$ cases (Table 12). ${ }^{10}$

Table 12: Comparative studies of peritoneal factors.

\begin{tabular}{|ll|ll|}
\hline \hline Peritoneal factors & $\begin{array}{l}\text { Sajida } \\
\text { et al }\end{array}$ & $\begin{array}{l}\text { Godinjak } \\
\text { et al }^{10}\end{array}$ & $\begin{array}{l}\text { Present } \\
\text { study }\end{array}$ \\
\hline Endometriosis & $8 \%$ & $14.16 \%$ & $7.5 \%$ \\
\hline Pelvic adhesions & $11.2 \%$ & $11.11 \%$ & $4.11 \%$ \\
\hline
\end{tabular}

In the present study, it reveals tubal factors $(28.3 \%)$ are the most common cause of infertility, followed by ovarian in $28.3 \%$, peritoneal in $11.3 \%$ and uterine in $10.8 \%$ of cases. The studies conducted by Sajida et al also found tubal factor as commonest cause, Godinjak $\mathrm{Z}$ et al, found peritoneal factor is commonest cause..$^{9,10}$ (Table 13).

Table 13: Comparative studies of various factors of infertility in laparoscopy.

\begin{tabular}{|ll|ll|}
\hline Factors & $\begin{array}{l}\text { Sajida } \\
\text { et al }\end{array}$ & $\begin{array}{l}\text { Godinjak } \\
\text { et } \text { al }^{\mathbf{1 0}}\end{array}$ & $\begin{array}{l}\text { Present } \\
\text { study }\end{array}$ \\
\hline Uterine & $4.8 \%$ & $8.6 \%$ & $10.8 \%$ \\
\hline Tubal & $35.4 \%$ & $13.3 \%$ & $28.3 \%$ \\
\hline Ovarian & $24.1 \%$ & $6.6 \%$ & $28.3 \%$ \\
\hline Peritoneal & $19.2 \%$ & $25.2 \%$ & $11.3 \%$ \\
\hline Unexplained & $16.5 \%$ & - & $22 \%$ \\
\hline
\end{tabular}

Table 14: Comparative studies of various causes of infertility in hysteroscopy.

\begin{tabular}{|c|c|c|c|}
\hline Causes & $\begin{array}{l}\text { Sajida } \\
\text { et } \text { al }^{9}\end{array}$ & $\begin{array}{l}\text { Godinjak } \\
\text { et al } \text { al }^{10}\end{array}$ & $\begin{array}{l}\text { Present } \\
\text { study }\end{array}$ \\
\hline Submucous fibroid & $1.6 \%$ & $3.05 \%$ & $5.85 \%$ \\
\hline Submucous polyp & $9.6 \%$ & $7.22 \%$ & $3.3 \%$ \\
\hline Intrauterine adhesion & $3.2 \%$ & $0.83 \%$ & $1 \%$ \\
\hline Uterine anomaly & $12.9 \%$ & $5.27 \%$ & $3.3 \%$ \\
\hline
\end{tabular}

In the present study submucous fibroid (5.8\%) is the most common pathology detected by hysteroscopy, it causes distortion of the endometrial cavity and implantation failure. submucous fibroid present in $3.3 \%$, uterine anomalies $3.3 \%$, intrauterine adhesion $0.8 \%$ of cases. Uterine anomalies which was undiagnosed by prior USG and other routine investigations, was also diagnosed during diagnostic hysteroscopy. Uterine anomalies usually cause recurrent pregnancy loss and pregnancy outcome dramatically improves after surgical correction 
in these patients. Godinjak $\mathrm{Z}$ et al, found endometrial polyp in $7.22 \%$, Sajida et al, found uterine anomalies in $12.9 \%$ are the most common causes detected in hysteroscopy (Table 14)..$^{9,10}$

In this study, statistically significant association was found between duration of infertility and type of infertility.

\section{CONCLUSION}

From this study, it is concluded that the diagnostic hysteroscopy and laparoscopy is an effective and safe tool in evaluation of female infertility. It provides direct and magnified view of all pelvic organs.

Diagnostic hysterolaparoscopy is a "definitive day-care procedure" in evaluation of infertility. It helps in the diagnosis of specific causes of infertility, which is not diagnosed by other investigations like hormonal study, USG and HSG.

It is an acceptable and feasible procedure, because it has the benefit of shorter hospital stay, less post-operative pain and quick return of routine activity.

From this study, authors can conclude that combined diagnostic hysterolaparoscopy is the gold standard tool in the evaluation of female infertility.

\section{Clinical significance}

Infertility is one of the most troublesome problem not only for the patient but also for the obstetrician treating them. It becomes a big task in both diagnosing and managing infertility due to a wide spectrum of causes it has. With advances in minimal invasive surgery and better visualization, hysterolaparoscopy can be considered as an important tool which can be made to use. Hence diagnostic hysterolaparoscopy can be used as an "Onetime Approach" by evaluation and therapeutic procedures can also be done in the same sitting as needed.

Funding: No funding sources Conflict of interest: None declared

Ethical approval: The study was approved by the Institutional Ethics Committee

\section{REFERENCES}

1. Ombelet W, Cooke I, Dyer S, Serour G, Devroey P. Infertility and the provision of infertility medical services in developing countries. Human Reprod Update. 2008;14(6):605-21.

2. Shokeir TA, Shalan HM, El-Shafei MM. Significance of endometrial polyps detected hysteroscopically in eumenorrheic infertile women. J Obstet Gynaecol Res. 2004;30(2):84-9.

3. Perez-Medina T, Bajo-Arenas J, Salazar F, Redondo T, Sanfrutos L, Alvarez P. Endometrial polyps and their implication in the pregnancy rates of patients undergoing intrauterine insemination: a prospective, randomized study. Hum Reprod. 2005;20(6):1632-5.

4. Vander Borght M, Wyns C. Fertility and infertility: Definition and epidemiology. Clin Biochem. 2018;62:2-10.

5. Homer HA, Li TC, Cooke ID. The septate uterus: a review of management and reproductive outcome. Fertil Steril. 2000;73(1):1-14.

6. Grimbizis GF, Camus M, Tarlatzis BC, Bontis JN, Devroey P. Clinical implications of uterine malformations and hysteroscopic treatment results. Hum Reprod Update. 2001;7(2):161-74.

7. Kurkuri SN. The role of combined hysterolaparoscopy in the evaluation of female infertility as one step procedure: a retrospective analytical study of 250 patients. Int $\mathrm{J}$ Reprod Contracept Obstet Gynecol. 2016;5:396-401.

8. Mehta AV, Modi AP, Raval BM, Munshi SP, Patel SB, Dedharotiya SM. Role of diagnostic hysterolaparoscopy in the evaluation of infertility. Int J Reprod Contracept Obstet Gynecol. 2016;5:437-40.

9. Parveen SA, Khanam M. Role of combined diagnostic laparoscopy and simultaneous diagnostic hysteroscopy for evaluation of female subfertility factors. J Surg Pak. 2010;15(1):44-7.

10. Godinjak Z, Idrizbegovic E. Should diagnostic hysteroscopy be a routine procedure during diagnostic laparoscopy in infertile women? JBMS. 2008;8:44-7.

Cite this article as: Sutaria R, Singh R, Gopal S. Hysterolaparoscopy as a one-time approach in infertility: a prospective study. Int J Reprod Contracept Obstet Gynecol 2020;9:2992-7. 